\title{
Influence of iron and copper oxides on polychlorinated diphenyl ether formation in heterogeneous reactions
}

\author{
Wenxia Liu • Lianfeng Shen • Fawen Zhang • \\ Wenbin Liu $\cdot$ Minghui Zheng $\cdot$ Xitian Yang
}

Received: 12 December 2012 / Accepted: 1 February 2013 / Published online: 26 February 2013

(C) Springer-Verlag Berlin Heidelberg 2013

\begin{abstract}
Polychlorinated diphenyl ether (PCDE) has attracted great attention recently as an important type of environmental pollutant. The influence of iron and copper oxides on formation of PCDEs was investigated using laboratory-scale flow reactors under air and under nitrogen at $350^{\circ} \mathrm{C}$, a temperature corresponding to the post-combustion zone of a municipal solid waste incinerator. The results show that the $2,2^{\prime}, 3,4,4^{\prime}, 5,5^{\prime}, 6$-otachlorodiphenyl ether (OCDE) formed from the condensation of pentachlorophenol (PCP) and 1,2,4,5-tetrachlorobenzene $\left(\mathrm{Cl}_{4} \mathrm{Bz}\right)$ is the predominant congener formed on the $\mathrm{SiO}_{2} / \mathrm{Fe}_{2} \mathrm{O}_{3}$ surface with and without oxygen. This indicated that $\mathrm{HCl}$ elimination between $\mathrm{PCP}$ and $1,2,4,5-\mathrm{Cl}_{4} \mathrm{Bz}$ molecules formed $2,2^{\prime}, 3,4,4^{\prime}, 5,5^{\prime}, 6-\mathrm{OCDE}$ in the presence of $\mathrm{Fe}_{2} \mathrm{O}_{3}$. On the other hand, decachlorodiphenyl ether, nonachlorodiphenyl ether, and OCDE were the dominant products on the $\mathrm{SiO}_{2} / \mathrm{CuO}$ surface without oxygen, although the $2,2^{\prime}, 3,4,4^{\prime}, 5,5^{\prime}, 6-\mathrm{OCDE}$ was the dominant product on the $\mathrm{SiO}_{2} / \mathrm{CuO}$ surface with oxygen. Therefore, the presence of $\mathrm{Fe}_{2} \mathrm{O}_{3}$ and $\mathrm{CuO}$ influences the formation and homologue distribution of PCDEs, which shifted towards the lower chlorinated species. $\mathrm{Fe}_{2} \mathrm{O}_{3}$ can promote both the condensation and dechlorination reaction without oxygen. On the contrary, with oxygen, $\mathrm{Fe}_{2} \mathrm{O}_{3}$ suppresses the condensation of chlorobenzene and chlorophenol to form PCDEs and polychlorinated dibenzo$p$-dioxins and polychlorinated dibenzofurans ( $\mathrm{PCDD} / \mathrm{Fs}) . \mathrm{CuO}$
\end{abstract}

Responsible editor: Hongwen Sun

W. Liu $(\varangle) \cdot$ L. Shen $\cdot$ F. Zhang $\cdot$ X. Yang

Department of Environmental Sciences,

Henan Agricultural University,

Zhengzhou 450002, China

e-mail: hjxliuwenxia@163.com

W. Liu $\cdot$ W. Liu $\cdot$ M. Zheng

State Key Laboratory of Environmental Chemistry

and Ecotoxicology, Research Center for Eco-Environmental

Sciences, Chinese Academy of Sciences,

P.O. Box 2871, Beijing 100085, China can increase the formation of lower chlorinated PCDEs and PCDDs without oxygen. In conclusion, the different fly ash components have a major influence on PCDE emissions.

Keywords Polychlorinated diphenyl ethers (PCDEs) . Polychlorinated dibenzo- $p$-dioxins and dibenzofurans (PCDD/Fs) · Polychlorophenol · Polychlorobenzene . Metal oxide $\cdot$ Model fly ash $\cdot$ Heterogeneous reactions

$\begin{array}{ll}\text { Abbreviations } \\ \mathrm{Cl}_{4} \mathrm{Bz} & \text { Tetrachlorobenzene } \\ \mathrm{MSWI} & \text { Municipal solid waste incinerator } \\ \mathrm{HxCDD} & \text { Hexachlorodibenzo- } p \text {-dioxin } \\ \mathrm{HxCDE} & \text { Hexachlorodiphenyl ether } \\ \mathrm{HxCDF} & \text { Hexachlorodibenzofurans } \\ \mathrm{HpCDD} & \text { Heptachlorodibenzo- } p \text {-dioxin } \\ \mathrm{HpCDE} & \text { Heptachlorodiphenyl ether } \\ \mathrm{HpCDF} & \text { Heptachlorodibenzofuran } \\ \text { OCDD } & \text { Octachlorodibenzo- } p \text {-dioxin } \\ \text { OCDE } & \text { Octachlorodiphenyl ether } \\ \text { NonaCDE } & \text { Nonachlorodiphenyl ether } \\ \text { DecaCDE } & \text { Decachlorodiphenyl ether } \\ \text { PCDDs } & \text { Polychlorinated dibenzo- } p \text {-dioxins } \\ \text { PCDEs } & \text { Polychlorinated diphenyl ethers } \\ \text { PCDFs } & \text { Polychlorinated dibenzofurans } \\ \text { PCP } & \text { Pentachlorophenol }\end{array}$

\section{Introduction}

Polychlorinated diphenyl ethers (PCDEs) are a group of halogenated aromatic compounds that are structurally located between polychlorinated biphenyls (PCBs) and polychlorinated dibenzofuran (PCDFs). PCDEs mainly arise as by-products of technical chlorophenols and chlorinated phenoxyacetic acids during incomplete combustion (Nevalainen and Koistinen 1994). PCDEs are a group of ubiquitous pollutants, which have 
been detected in a number of environmental samples including sediments, mussels, fish, birds, seals, foodstuffs, and human tissue (Sinkkonen and Paasivirta 2000; Stanley et al. 1990; Koistinen et al. 1995a, 1997; Niimi et al. 1994). Wide distribution, high lipophilicity, and persistence of PCDEs have raised concern about their bioaccumulation, their potential biomagnification in the food webs, and their adverse effects (Domingo et al. 2006; Xu et al. 2010). Hence, PCDEs have attracted great attention recently as an important type of environmental pollutant.

Many chlorinated aromatic compounds are emitted by thermal processes and subsequently persist in the environment. PCDEs may be converted to more toxic polychlorinated dibenzo-p-dioxins and furans $(\mathrm{PCDD} / \mathrm{Fs})$ by photolysis or pyrolysis (Norström et al. 1977; Lindahl et al. 1980; Nito et al. 1997). Of particular note are those produced from municipal solid waste incinerators (MSWIs) (Koistinen et al. 1995b; Passivirta et al. 1986; Kurz and Ballschmiter 1995; Olie et al. 1977), which are known to be major sources of PCDEs and PCDD/Fs. PCDEs and PCDD/Fs become concentrated in fly ash by post-combustion processes, forming in the presence of oxygen, their precursors, and chlorine sources (Liu et al. 2008, 2011; Addink and Olie 1995; Tuppurainen et al. 1998). Therefore, an understanding of the post-combustion mechanism that generates chlorinated aromatic compounds, including PCDEs and PCDD/Fs, is essential for protecting human health, given the persistence of these compounds in the environment. However, there are far fewer accounts of the formation of PCDEs compared with PCDD/Fs.

Some work has been done to describe the formation of PCDEs in the post-combustion zone of MSWIs (Liu et al. 2011). The combustion temperature of MSWIs is usually very high $\left(700-900^{\circ} \mathrm{C}\right)$, whereas chlorinated aromatic compounds are formed readily at the lower temperature $\left(250-400{ }^{\circ} \mathrm{C}\right)$ of post-combustion zones (Milligan and Altwicker 1996; Mckay 2002), and their formation is strongly influenced by traces of metallic compounds in the real fly ash of MSWIs (Fujimori et al. 2009). PCDEs were formed from the precursor condensation on the simulated fly ash surface, including $\mathrm{SiO}_{2}$, $\mathrm{SiO}_{2} / \mathrm{FeCl}_{3}$, and $\mathrm{SiO}_{2} / \mathrm{CuCl}_{2}$ surfaces. However, fly ash is an extremely complex material, and there are not only metal chlorides but also metal oxides in municipal solid waste (Chin et al. 2012; Öberg et al. 2008; Fujimori et al. 2009; Altarawneh et al. 2009; Weber et al. 2002a, b, Lomnicki and Dellinger 2003a). Nevertheless, the less pronounced effects of the metal oxides on the PCDEs formation were reported. In the present study, the influence of fly ash ingredients such as $\mathrm{Fe}_{2} \mathrm{O}_{3}$ and $\mathrm{CuO}$ on the formation of PCDEs was investigated under air and nitrogen. Chlorophenol and chlorobenzene have been discussed as potential precursors of PCDEs (Liu et al. 2008), which were found in the effluents from MSWIs (Ballschmiter et al. 1988). Moreover, the tetrachloro- to hexachloro-benzene and tetrachloro- to pentachloro-phenol are dominating over the lower chlorinated congeners in the combustion effluences. Thus, pentachlorophenol (PCP) and 1,2,4,5-tetrachlorobenzene $\left(1,2,4,5-\mathrm{Cl}_{4} \mathrm{Bz}\right)$ were chosen as the model compounds. The study may get an initial understanding of the formation of PCDEs during post-combustion reactions. Therefore, it is important for the development of control techniques and strategies to reduce the emission of PCDEs in MSWIs.

\section{Experimental section}

\section{Materials}

The reagents, silicon dioxide $\left(\mathrm{SiO}_{2}\right.$; Beijing Chemical Reagents Company, Beijing, China), $\mathrm{Fe}_{2} \mathrm{O}_{3}$ (Shantou Xilong Chemical Plant, Shantou city, Guangdong, China), $\mathrm{CuO}$ (Beijing Hongxing Chemical Plant, Beijing, China), and 1,2,4,5-tetrachlorobenzene $\left(1,2,4,5-\mathrm{Cl}_{4} \mathrm{Bz}\right.$; SchuchardtMunchen Co., Germany) were all of analytical reagent grade. Pentachlorophenol (PCP) was purified to remove PCDE and PCDD/F impurities (Qian et al. 2005). Prior to the experiments, the silicon dioxide was Soxhlet extracted with toluene, air-dried at room temperature, and then heated at $700{ }^{\circ} \mathrm{C}$ for $6 \mathrm{~h}$. The copper oxide was ground in a mortar before use. The synthetic fly ash $\left(95 \% \mathrm{SiO}_{2}\right.$ and $5 \%$ metal oxide) was prepared by mechanical mixing. All solvents used in this study were pesticide grade (Fisher Scientific, USA).

\section{Experimental procedures}

The experiments on the effects of fly ash composition on $\mathrm{PCDE}$ and $\mathrm{PCDD} / \mathrm{F}$ formation were carried out in a flow reactor system at the temperature of $350{ }^{\circ} \mathrm{C}$. A schematic diagram of the experimental apparatus is shown in Fig. 1. The quartz reaction tube $(60 \mathrm{~cm} \times 6 \mathrm{~mm}$ i.d. $)$ was placed in the heated zone of a tube furnace. A total of $20 \mathrm{~g}\left[19 \mathrm{~g} \mathrm{SiO}_{2}\right.$ and $1 \mathrm{~g}$ metal oxide, metal oxide $5 \%(\mathrm{~m} / \mathrm{m})]$ of the granulated simulated fly ash was packed in a reaction tube, and the

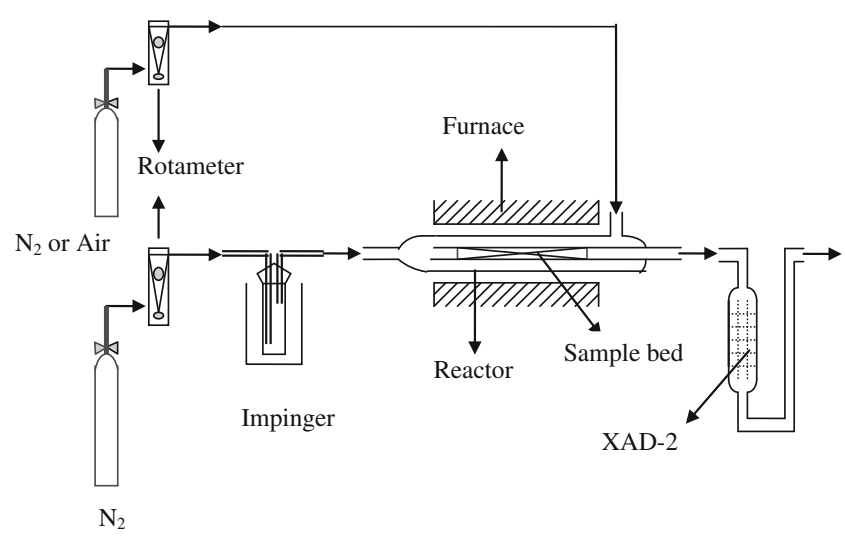

Fig. 1 Schematic of experimental apparatus 
reaction tube was then placed in the tube furnace. The carrier gas (either nitrogen or air) was carried into the reactor in a Teflon tube from compressed gas cylinders at flow rates of $40 \mathrm{ml} / \mathrm{min}$ controlled by a calibrated rotameter. The chlorinated organic precursors ( $4 \mathrm{mg} \mathrm{PCP}$ and $4 \mathrm{mg} 1,2,4,5-\mathrm{Cl}_{4} \mathrm{Bz}$ ) were fed into the reactor by blowing $\mathrm{N}_{2}$ at a velocity of $10 \mathrm{ml} / \mathrm{min}$ through a heated miniature impinger. The tube furnace temperature and the gas flow rate were kept constant throughout the experiment for $2 \mathrm{~h}$. For the sampling of the PCDEs and PCDD/Fs, the outlet gas from the reaction tube was passed through an ice-cooled XAD-2. Between runs, the glassware was rinsed with detergent and water, followed by toluene and acetone. The feed system was cleaned with flowing air at the temperature of $250{ }^{\circ} \mathrm{C}$. A blank test was performed before each experiment to check the contamination levels. Each experiment was performed in triplicate to ensure the repeatability of the experiments.
Analytical methods

The inside of the tubing was rinsed with dichloromethane and this rinsate was combined with the XAD-2 extract. The reaction products were extracted, identified, and then quantified using an Agilent 6890 GC equipped with a 5973 MSD (Liu et al. 2011).

\section{Results and discussion}

The PCDE distribution on the surface of $\mathrm{SiO}_{2} / \mathrm{Fe}_{2} \mathrm{O}_{3}$

The PCDE content formed by the condensation of PCP and $1,2,4,5-\mathrm{Cl}_{4} \mathrm{Bz}$ on the surface of $\mathrm{SiO}_{2} / \mathrm{CuO}$ and $\mathrm{SiO}_{2} / \mathrm{Fe}_{2} \mathrm{O}_{3}$ in air and in nitrogen (with and without oxygen) is presented in Table 1. The homologue profiles of the PCDEs are shown in Fig. 2. The dominant PCDE homologue on the surface of
Table 1 Formation of PCDEs from condensation of $\mathrm{PCP}$ and $1,2,4,5-\mathrm{Cl}_{4} \mathrm{Bz}$ at $350{ }^{\circ} \mathrm{C}(\mathrm{PCP} /$ $\left.\mathrm{Cl}_{4} \mathrm{Bz}=1: 1\right)$

${ }^{\mathrm{a}}$ Substitution pattern of congener not identified. Mono- to PentaCDE was below detection limit n.d. $<1.0 \mathrm{ng} / \mathrm{mg}$

\begin{tabular}{|c|c|c|c|c|c|c|}
\hline \multirow[t]{3}{*}{ Congeners } & \multicolumn{6}{|c|}{ PCDE content (ng/mg, $n=3)$} \\
\hline & \multicolumn{2}{|l|}{$\mathrm{SiO}_{2}$} & \multicolumn{2}{|c|}{$\mathrm{SiO}_{2} / \mathrm{Fe}_{2} \mathrm{O}_{3}$} & \multicolumn{2}{|c|}{$\mathrm{SiO}_{2} / \mathrm{CuO}$} \\
\hline & $\mathrm{N}_{2}$ & Air & $\mathrm{N}_{2}$ & Air & $\mathrm{N}_{2}$ & Air \\
\hline DecaCDE & $53 \pm 3$ & $46 \pm 2$ & $38 \pm 5$ & $9 \pm 4$ & $91 \pm 3$ & $90 \pm 4$ \\
\hline $2,2^{\prime}, 3,3^{\prime}, 4,5,5^{\prime}, 6,6^{\prime}-$ NonaCDE & n.d. & $13 \pm 3$ & n.d. & n.d. & $22 \pm 3$ & $2.2 \pm 2$ \\
\hline $2,2^{\prime}, 3,3^{\prime}, 4,4^{\prime}, 5,5^{\prime}, 6-$ NonaCDE & n.d. & $11 \pm 2$ & $26 \pm 3$ & n.d. & $25 \pm 2$ & $88 \pm 2$ \\
\hline $2,2^{\prime}, 3,3^{\prime}, 4,4^{\prime}, 5,6,6^{\prime}$-NonaCDE & n.d. & $32 \pm 3$ & $73 \pm 2$ & n.d. & $34 \pm 3$ & $111 \pm 3$ \\
\hline$\Sigma$ NonaCDE & n.d. & $56 \pm 2$ & $99 \pm 7$ & 0 & $81 \pm 3$ & $201 \pm 2$ \\
\hline $\operatorname{OCDE}(1)^{\mathrm{a}}$ & n.d. & $3.7 \pm 0.6$ & n.d. & n.d. & $5.5 \pm 1$ & n.d. \\
\hline $2,2^{\prime}, 3,4,4^{\prime}, 5,5^{\prime}, 6-\mathrm{OCDE}$ & $1,134 \pm 9$ & $152 \pm 6$ & $1,116 \pm 5$ & $27 \pm 1$ & $30 \pm 2$ & $804 \pm 3$ \\
\hline $\operatorname{OCDE}(3)^{\mathrm{a}}$ & n.d. & $2.6 \pm 0.5$ & n.d. & n.d. & $9.4 \pm 2$ & n.d. \\
\hline $\operatorname{OCDE}(4)^{\mathrm{a}}$ & n.d. & $1.7 \pm 0.4$ & n.d. & n.d. & $17 \pm 2$ & n.d. \\
\hline $\operatorname{OCDE}(5)^{\mathrm{a}}$ & n.d. & n.d. & n.d. & n.d. & $4.6 \pm 1$ & n.d. \\
\hline $\operatorname{OCDE}(6)^{\mathrm{a}}$ & n.d. & n.d. & n.d. & n.d. & $6.0 \pm 1$ & n.d. \\
\hline$\Sigma \mathrm{OCDE}$ & $1,134 \pm 9$ & $160 \pm 5$ & $1,116 \pm 5$ & $27 \pm 1$ & $72 \pm 2$ & $804 \pm 3$ \\
\hline $\operatorname{HpCDE}(1)^{\mathrm{a}}$ & $10 \pm 2$ & $12 \pm 3$ & $48 \pm 2$ & n.d. & n.d. & $7.1 \pm 1$ \\
\hline $\operatorname{HpCDE}(2)^{\mathrm{a}}$ & n.d. & $4.2 \pm 0.5$ & $166 \pm 3$ & n.d. & $8.2 \pm 2$ & $12 \pm 1$ \\
\hline $\operatorname{HpCDE}(3)^{\mathrm{a}}$ & n.d. & $2.7 \pm 0.6$ & n.d. & n.d. & n.d. & n.d. \\
\hline $\operatorname{HpCDE}(4)^{\mathrm{a}}$ & $63 \pm 4$ & $3.6 \pm 0.5$ & n.d. & n.d. & n.d. & n.d. \\
\hline $\operatorname{HpCDE}(5)^{\mathrm{a}}$ & n.d. & $36 \pm 3$ & $33 \pm 2$ & n.d. & n.d. & n.d. \\
\hline $\operatorname{HpCDE}(6)^{\mathrm{a}}$ & n.d. & n.d. & $45 \pm 2$ & n.d. & $6.2 \pm 2$ & $7.5 \pm 1$ \\
\hline$\Sigma \mathrm{HpCDE}$ & $73 \pm 3$ & $59 \pm 2$ & $293 \pm 3$ & n.d. & $14.4 \pm 2$ & $27 \pm 1$ \\
\hline $\operatorname{HxCDE}(1)^{\mathrm{a}}$ & n.d. & $44 \pm 3$ & $17 \pm 2$ & n.d. & n.d. & n.d. \\
\hline $\operatorname{HxCDE}(2)^{\mathrm{a}}$ & n.d. & n.d. & $5.7 \pm 1$ & n.d. & n.d. & n.d. \\
\hline $\operatorname{HxCDE}(3)^{\mathrm{a}}$ & n.d. & n.d. & $10 \pm 2$ & n.d. & $5.3 \pm 1$ & $6.2 \pm 1$ \\
\hline $\operatorname{HxCDE}(4)^{\mathrm{a}}$ & n.d. & n.d. & $6.8 \pm 1$ & n.d. & n.d. & n.d. \\
\hline $\operatorname{HxCDE}(5)^{\mathrm{a}}$ & n.d. & n.d. & $3.9 \pm 1$ & n.d. & n.d. & n.d. \\
\hline $\operatorname{HxCDE}(6)^{\mathrm{a}}$ & n.d. & n.d. & $8.3 \pm 1$ & n.d. & n.d. & n.d. \\
\hline$\Sigma \mathrm{HxCDE}$ & n.d. & $44 \pm 3$ & $52 \pm 2$ & n.d. & $5.3 \pm 1$ & $6.2 \pm 1$ \\
\hline$\Sigma$ PCDEs & $1,260 \pm 10$ & $365 \pm 4$ & $1,598 \pm 4$ & $36 \pm 4$ & $265 \pm 4$ & $1,128 \pm 3$ \\
\hline
\end{tabular}




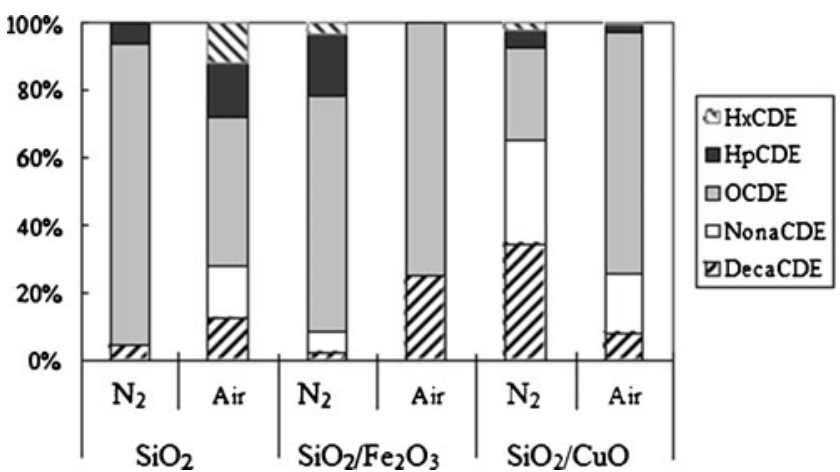

Fig. 2 PCDEs homologue patterns under nitrogen and air

$\mathrm{SiO}_{2} / \mathrm{Fe}_{2} \mathrm{O}_{3}$ at $350^{\circ} \mathrm{C}$ in air was $2,2^{\prime}, 3,4,4^{\prime}, 5,5^{\prime}, 6$-octachlorodiphenyl ether (OCDE), with small amounts of decachlorodiphenyl ether (DecaCDE). Two nonachlorodiphenyl ether (NonaCDE), four heptachlorodiphenyl ether (HpCDE), and six hexachlorodiphenyl ether ( $\mathrm{HxCDE})$ isomers were also detected besides OCDE and DecaCDE, on the surface of $\mathrm{SiO}_{2} / \mathrm{Fe}_{2} \mathrm{O}_{3}$ under nitrogen. $\mathrm{HCl}$ elimination between PCP and 1,2,4,5-Cl ${ }_{4} \mathrm{Bz}$ molecules formed $2,2^{\prime}, 3,4,4^{\prime}, 5,5^{\prime}, 6-$ OCDE, while DecaCDE was produced by the elimination of $\mathrm{H}_{2} \mathrm{O}$ between two PCP molecules. The content of $2,2^{\prime}, 3,4,4^{\prime}, 5,5^{\prime}, 6$-OCDE was consistently higher than that of DecaCDE. However, more congeners, including NonaCDE, HpCDE, and $\mathrm{HxCDE}$, were formed on the $\mathrm{SiO}_{2} / \mathrm{Fe}_{2} \mathrm{O}_{3}$ surface than on the surface of $\mathrm{SiO}_{2}$ under nitrogen. It can be concluded that the dechlorination reaction occurs more easily on the surface of $\mathrm{SiO}_{2} / \mathrm{Fe}_{2} \mathrm{O}_{3}$ than $\mathrm{SiO}_{2}$ under nitrogen.

$\mathrm{HpCDE}$ and $\mathrm{HxCDE}$ were not detected in reactions that occurred under air, while more isomers of $\mathrm{HpCDE}$ and $\mathrm{HxCDE}$ were formed under nitrogen. However, no congeners of monochlorodiphenyl ether to pentachlorodiphenyl ether (mono- to pentaCDE) were detected in any experiment. The substitution pattern for some isomers could not be identified under the analytical conditions, so the serial number was used to denote the various isomers. Both of the number of PCDE congener species and the amount of total PCDEs were greater under nitrogen than under air on the surface of $\mathrm{SiO}_{2} / \mathrm{Fe}_{2} \mathrm{O}_{3}$. This indicates that the presence of oxygen can prevent the production of PCDEs during the reactions of $\mathrm{PCP}$ and 1,2,4,5$\mathrm{Cl}_{4} \mathrm{Bz}$ on the $\mathrm{SiO}_{2} / \mathrm{Fe}_{2} \mathrm{O}_{3}$ surface, which was consistent with the results on the surface of $\mathrm{SiO}_{2}$ (Liu et al. 2011). Other competitive reaction pathways may be available in the reaction system. It has been reported that on metal oxides, chlorinated benzenes and chlorinated phenols can decompose directly via ring-cracking into small organic molecules such as formates and acetates, and even into $\mathrm{CO}_{2}, \mathrm{CO}$, and $\mathrm{H}_{2} \mathrm{O}$, particularly in the presence of oxygen (Zhang et al. 2008; Krishnamoorthy et al. 2000; Hetrick et al. 2008, Lomnicki and Dellinger 2003b). The addition of oxygen to the system may have promoted the reaction toward the direct oxidative ring-cracking decomposition of $\mathrm{PCP}$ and $1,2,4,5-\mathrm{Cl}_{4} \mathrm{Bz}$, and thus the formation of PCDEs is reduced.

It can be seen that the PCDE homologue profiles were different in air and under nitrogen (Fig. 2). The amount of SOCDE comprised $70 \%$ and $75 \%$ of the total PCDEs, while DecaCDE comprised $2.4 \%$ and $25 \%$ of the total PCDEs under nitrogen and air, respectively. The amount of $\Sigma$ NonaCDE, $\Sigma \mathrm{HpCDE}$, and $\Sigma \mathrm{HxCDE}$ comprised $6.2 \%$, $18 \%$, and $3.2 \%$ of the total PCDEs, respectively, under nitrogen on the $\mathrm{SiO}_{2} / \mathrm{Fe}_{2} \mathrm{O}_{3}$ surface. Therefore, the condensation of PCP with $1,2,4,5-\mathrm{Cl}_{4} \mathrm{Bz}$ to form $\mathrm{OCDE}$ was the predominant reaction in the system, while the condensation of two PCP molecules to form DecaCDE occurred less on the $\mathrm{SiO}_{2} / \mathrm{Fe}_{2} \mathrm{O}_{3}$ surface, which was consistent with the results from the condensation of PCP with $1,2,4,5-\mathrm{Cl}_{4} \mathrm{Bz}$ on the surface of $\mathrm{SiO}_{2}$ (Liu et al. 2011). This result was also consistent with the findings of Liu et al. (2008), who described the formation mechanism of PCDEs in homogeneous gas phase reactions. The presence of $\mathrm{Fe}_{2} \mathrm{O}_{3}$ does not change the reaction processes of $\mathrm{PCP}$ and $1,2,4,5-\mathrm{Cl}_{4} \mathrm{Bz}$. However, there were more PCDE congener species on the $\mathrm{SiO}_{2} / \mathrm{Fe}_{2} \mathrm{O}_{3}$ surface than on the $\mathrm{SiO}_{2}$ surface under nitrogen. The condensation of polychlorophenol and polychlorobenzene generating PCDEs can be a radical/molecule reaction mechanism (Louw and Ahonkhai 2002; Bozzelli et al. 1991) . Polychlorophenoxy radicals were formed on the simulated fly ash under heated condition and polychlorophenoxy radical addition reactions to polychlorobenzene formed the ether linkages, and following the elimination of chlorination, PCDEs were formed. Under nitrogen atmosphere, $\mathrm{Fe}_{2} \mathrm{O}_{3}$ can react with hydrogen chloride, which was eliminated between polychlorophenol and polychlorobenzene molecules; therefore, $\mathrm{Fe}_{2} \mathrm{O}_{3}$ catalyzes the formation of PCDEs without oxygen. On the other hand, the lower chlorinated PCDEs congeners were formed due to $\mathrm{Fe}_{2} \mathrm{O}_{3}$ dechlorination action under nitrogen atmosphere.

\section{The PCDE distribution on the surface of $\mathrm{SiO}_{2} / \mathrm{CuO}$}

Over the $\mathrm{SiO}_{2} / \mathrm{CuO}$ surface, DecaCDE, NonaCDE, and OCDE were the main PCDE homologues under nitrogen, while OCDE was the main PCDE homologue under air. Three isomers of NonaCDE, six isomers of OCDE, two isomers of $\mathrm{HpCDE}$, and one isomer of $\mathrm{HxCDE}$ were detected on the $\mathrm{SiO}_{2} / \mathrm{CuO}$ surface under nitrogen, whereas other OCDE isomers in addition to $2,2^{\prime}, 3,4,4^{\prime}, 5,5^{\prime}, 6-\mathrm{OCDE}$ were not detected under air. The amounts of total PCDEs were $265 \mathrm{ng} / \mathrm{mg}$ and $1,128 \mathrm{ng} / \mathrm{mg}$ under nitrogen and air, respectively. There were more PCDE products without oxygen than with oxygen, but the amount of total PCDEs formed was lower under nitrogen than air on the $\mathrm{SiO}_{2} / \mathrm{CuO}$ surface. On the $\mathrm{SiO}_{2} / \mathrm{CuO}$ surface under oxidative condition, the formation of PCDEs involves 
two different surface-mediated mechanisms (Lomnicki and Dellinger 2003a), which are Eley-Rideal and LangmuirHinshelwood. Eley-Rideal mechanism involves the reaction between the adsorbed species and a gas-phase molecule, while Langmuir-Hinshelwood is the reaction between two surfaceadsorbed species. The experiment confirms that upon adsorption of chlorophenol over copper oxide, the interaction of adsorbed phenolate species with the surface results in the formation of phenoxy radical (Shi and Yuan 1996; Lomnicki and Dellinger 2003a). The surface-associated chlorophenoxyl can react with gas-phase chlorobenzenes to form PCDEs, which are produced as a result of an Eley-Rideal mechanism. Pyrolytic condition resulted in the significant surface oxygen deficit, and this resulted in PCP remaining adsorbed on the surface rather than being oxidized into phenoxy radical. Oxygen affects the rate of formation. Therefore, the addition of oxygen could increase PCDEs formation on the $\mathrm{SiO}_{2} / \mathrm{CuO}$ surface.

The content of total PCDEs was significantly higher on the $\mathrm{SiO}_{2} / \mathrm{CuO}$ surface than on the $\mathrm{SiO}_{2} / \mathrm{CuCl}_{2}$ surfaces under both atmospheres (Liu et al. 2011). Therefore, $\mathrm{CuO}$ can promote PCDE formation more effectively than $\mathrm{CuCl}_{2}$ from precursors in heterogeneous reactions.

The proportions of DecaCDE, NonaCDE, and OCDE to total PCDEs were $34 \%, 31 \%$, and $27 \%$, on the $\mathrm{SiO}_{2} / \mathrm{CuO}$ surface under nitrogen, while their proportions were $8 \%, 18 \%$, and $71 \%$ under air, respectively (Fig. 2). 2,2',3,4,4',5,5',6OCDE is the dominant PCDE homologue product formed on the surface of $\mathrm{SiO}_{2} / \mathrm{CuO}$ under air. However, the proportions of DecaCDE were $94 \%$ and $77 \%$ on the $\mathrm{SiO}_{2} / \mathrm{CuCl}_{2}$ surface under nitrogen and air, respectively (Liu et al. 2011). Thus, the presence of $\mathrm{CuO}$ and $\mathrm{CuCl}_{2}$ influenced the PCDE homologue profiles, and the distribution shifted toward the less substituted chlorinated congeners on the surface of $\mathrm{SiO}_{2} / \mathrm{CuO}$ than $\mathrm{SiO}_{2} / \mathrm{CuCl}_{2}$.

The amount of PCDEs was higher on the $\mathrm{SiO}_{2} / \mathrm{Fe}_{2} \mathrm{O}_{3}$ surface than on the $\mathrm{SiO}_{2} / \mathrm{CuO}$ surface under nitrogen. Moreover, the amount of PCDEs was higher on the $\mathrm{SiO}_{2} / \mathrm{Fe}_{2} \mathrm{O}_{3}$ surface than on the $\mathrm{SiO}_{2}$ surface under nitrogen, while the amount of PCDEs was lower on the $\mathrm{SiO}_{2} / \mathrm{CuO}$ surface than on the $\mathrm{SiO}_{2}$ surface. Without oxygen, $\mathrm{Fe}_{2} \mathrm{O}_{3}$ catalyzes the formation of PCDEs, whereas $\mathrm{CuO}$ reduces PCDEs formation. In addition, the effect of oxygen on the PCDEs formation needs to be noticed. Compared with reaction condition of nitrogen, the amount of PCDEs remarkably reduced by $71 \%$ and $97.7 \%$, and increased by $325.7 \%$ under air on the $\mathrm{SiO}_{2}, \mathrm{SiO}_{2} / \mathrm{Fe}_{2} \mathrm{O}_{3}$, and $\mathrm{SiO}_{2} / \mathrm{CuO}$ surfaces, respectively. Reaction atmosphere was an important factor for the formation of PCDEs on simulated fly ash surface. In air, the amount of PCDEs was higher on the $\mathrm{SiO}_{2} / \mathrm{CuO}$ surface compared with that on the $\mathrm{SiO}_{2} / \mathrm{Fe}_{2} \mathrm{O}_{3}$ and $\mathrm{SiO}_{2}$ surfaces. However, the amount of PCDEs was lower on the $\mathrm{SiO}_{2} / \mathrm{Fe}_{2} \mathrm{O}_{3}$ surface than on the $\mathrm{SiO}_{2}$ surface. This indicated that with oxygen, $\mathrm{CuO}$ facilitated PCDE formation, while $\mathrm{Fe}_{2} \mathrm{O}_{3}$ impeded PCDE formation. In heterogeneous reactions with oxygen, $\mathrm{Fe}_{2} \mathrm{O}_{3}$ reduces the catalytic production of PCDEs, but without oxygen, $\mathrm{CuO}$ reduces the catalytic production of PCDEs. This indicates that the presence of $\mathrm{Fe}_{2} \mathrm{O}_{3}$ and $\mathrm{CuO}$ influence PCDE formation from the reactions of $\mathrm{PCP}$ and $1,2,4,5-\mathrm{Cl}_{4} \mathrm{Bz}$ in heterogeneous reactions. $\mathrm{Fe}_{2} \mathrm{O}_{3}$ and $\mathrm{CuO}$ have significant different effects on PCDEs formation, with and without oxygen.

PCDEs contents were changed by $-36.7 \%, 26.8 \%$, $-93.3 \%$, and $-78.96 \%$ under nitrogen atmosphere, and $-27.4 \%,-90.1 \%,-81.9 \%$, and $209.0 \%$ under air atmosphere on the $\mathrm{SiO}_{2} / \mathrm{FeCl}_{3}, \mathrm{SiO}_{2} / \mathrm{Fe}_{2} \mathrm{O}_{3}, \mathrm{SiO}_{2} / \mathrm{CuCl}_{2}$, and $\mathrm{SiO}_{2} / \mathrm{CuO}$ surfaces compared to the $\mathrm{SiO}_{2}$ surface, respectively (Liu et al. 2011). Therefore, the catalytic activities of the $\mathrm{Cu}$ and $\mathrm{Fe}$ salts should be different on the formation of PCDEs. $\mathrm{Fe}_{2} \mathrm{O}_{3}$ under nitrogen atmosphere shows catalytic activities, while $\mathrm{CuO}$ have higher catalytic activities under air atmosphere on the formation of PCDEs.

The trend and relationship between PCDEs and PCDFs

The contents of PCDD/Fs formed from the condensation of PCP and 1,2,4,5- $\mathrm{Cl}_{4} \mathrm{Bz}$ are shown in Table 2. The observed products included octachlorodibenzo- $p$-dioxin (OCDD), heptachlorodibenzo- $p$-dioxin (HpCDD), hexachlorodibenzo$p$-dioxin (HxCDD), pentachlorodibenzo-p-dioxin (PeCDD), heptachlorodibenzofuran (HpCDF), hexachlorodibenzofuran (HxCDF), and pentachlorodibenzofuran (PeCDF). However, octachlorodibenzofuran (OCDF) and tetrachlorodibenzo- $p$-dioxin and dibenzofuran (TetraCDD/F) were not detected in the study. The amounts of OCDD and HpCDD were $44 \%$ and $48 \%$ of the total PCDD/Fs measured on the $\mathrm{SiO}_{2} / \mathrm{Fe}_{2} \mathrm{O}_{3}$ surface (Fig. 3), respectively, and their amounts were respectively $54 \%$ and $25 \%$ of the total PCDD/Fs on the $\mathrm{SiO}_{2} / \mathrm{CuO}$ surface under nitrogen. On the $\mathrm{SiO}_{2}$ surface under nitrogen and air, the amounts of OCDD were above $91 \%$ of the total PCDD/Fs measured, and the amounts of OCDD were more than $98 \%$ of total $\mathrm{PCDD} / \mathrm{Fs}$ on the $\mathrm{SiO}_{2} / \mathrm{FeCl}_{3}$ and $\mathrm{SiO}_{2} / \mathrm{CuCl}_{2}$ surfaces under both atmospheres (Liu et al. 2011). This indicates that the presence of $\mathrm{Fe}_{2} \mathrm{O}_{3}$ and $\mathrm{CuO}$ contributes to the formation of some less chlorinated PCDDs.

The amount of PCDD/Fs formed was higher on the $\mathrm{SiO}_{2} / \mathrm{Fe}_{2} \mathrm{O}_{3}$ surface without oxygen than that with oxygen, but this pattern was reversed on the $\mathrm{SiO}_{2} / \mathrm{CuO}$ surface. In addition, the amounts of PCDEs and PCDD/Fs were obviously lower on the $\mathrm{SiO}_{2} / \mathrm{Fe}_{2} \mathrm{O}_{3}$ surface under air than those under nitrogen. This indicates that the presence of oxygen can prevent the production of PCDEs and PCDD/Fs during the reactions of $\mathrm{PCP}$ and $1,2,4,5-\mathrm{Cl}_{4} \mathrm{Bz}$ on the $\mathrm{SiO}_{2} / \mathrm{Fe}_{2} \mathrm{O}_{3}$ surface. Other competitive reaction pathways may be available in the reaction system (Zhang et al. 2008; Krishnamoorthy et al. 2000; Hetrick et al. 2008). The addition of oxygen to the 
Table 2 Formation of PCDD/Fs from condensation of $\mathrm{PCP}$ and $1,2,4,5-\mathrm{Cl}_{4} \mathrm{Bz}$ at $350{ }^{\circ} \mathrm{C}$ $\left(\mathrm{PCP} / \mathrm{Cl}_{4} \mathrm{Bz}=1: 1\right)$
OCDF and Tetra- to PentaCDD/ DF were below detection limit n.d. $<1.0 \mathrm{ng} / \mathrm{mg}$

${ }^{\text {a }}$ Substitution pattern of congener was not identified

\begin{tabular}{|c|c|c|c|c|c|c|}
\hline \multirow[t]{3}{*}{ Congeners } & \multicolumn{6}{|c|}{ PCDD/Fs content (ng/mg, $n=3)$} \\
\hline & \multicolumn{2}{|l|}{$\mathrm{SiO}_{2}$} & \multicolumn{2}{|c|}{$\mathrm{SiO}_{2} / \mathrm{Fe}_{2} \mathrm{O}_{3}$} & \multicolumn{2}{|c|}{$\mathrm{SiO}_{2} / \mathrm{CuO}$} \\
\hline & $\mathrm{N}_{2}$ & Air & $\mathrm{N}_{2}$ & Air & $\mathrm{N}_{2}$ & Air \\
\hline OCDD & $3,359 \pm 10$ & $2,568 \pm 9$ & $2,453 \pm 6$ & $12 \pm 2$ & $1,922 \pm 5$ & $3,786 \pm 6$ \\
\hline 1,2,3,4,6,7,9-HpCDD & $44 \pm 6$ & $39 \pm 3$ & $1,255 \pm 4$ & n.d. & $417 \pm 3$ & $48 \pm 2$ \\
\hline $1,2,3,4,6,7,8-\mathrm{HpCDD}$ & $175 \pm 5$ & $106 \pm 6$ & $1,465 \pm 3$ & n.d. & $486 \pm 3$ & $34 \pm 2$ \\
\hline$\Sigma \mathrm{HpCDD}$ & $219 \pm 6$ & $145 \pm 5$ & $2720 \pm 4$ & n.d. & $903 \pm 3$ & $82 \pm 2$ \\
\hline $\operatorname{HpCDF}(1)^{\mathrm{a}}$ & $11 \pm 2$ & $10 \pm 2$ & $59 \pm 2$ & n.d. & $4.5 \pm 1$ & $6.2 \pm 1$ \\
\hline $\operatorname{HpCDF}(2)^{\mathrm{a}}$ & $1.8 \pm 0.3$ & $2.2 \pm 0.4$ & $26 \pm 2$ & n.d. & n.d. & $7.1 \pm 2$ \\
\hline $\operatorname{HpCDF}(3)^{\mathrm{a}}$ & n.d. & $2.7 \pm 0.5$ & n.d. & n.d. & n.d. & $9.4 \pm 2$ \\
\hline $1,2,3,4,7,8,9-\mathrm{HpCDF}$ & $2.4 \pm 0.3$ & $3.7 \pm 0.4$ & $41 \pm 2$ & n.d. & n.d. & n.d. \\
\hline $\operatorname{HpCDF}(4)^{\mathrm{a}}$ & $4.3 \pm 0.5$ & $2.9 \pm 0.3$ & $21 \pm 1$ & n.d. & n.d. & n.d. \\
\hline$\Sigma \mathrm{HpCDF}$ & $20 \pm 1.5$ & $22 \pm 2$ & $148 \pm 2$ & n.d. & $4.5 \pm 1$ & $22.7 \pm 2$ \\
\hline $\operatorname{HxCDD}(1)^{\mathrm{a}}$ & $4.0 \pm 0.5$ & $6.3 \pm 0.4$ & $54 \pm 2$ & n.d. & $109 \pm 3$ & n.d. \\
\hline $\operatorname{HxCDD}(2)^{\mathrm{a}}$ & $4.6 \pm 0.5$ & n.d & n.d. & n.d. & $310 \pm 3$ & n.d. \\
\hline $\operatorname{HxCDD}(3)^{\mathrm{a}}$ & n.d. & n.d. & $88 \pm 2$ & n.d. & $57 \pm 2$ & n.d. \\
\hline $1,2,3,4,7,8-\mathrm{HxCDD}$ & $2.6 \pm 0.3$ & $15 \pm 2$ & $22 \pm 2$ & n.d. & $83 \pm 2$ & $2.3 \pm 1$ \\
\hline $1,2,3,6,7,8-\mathrm{HxCDD}$ & n.d. & $9.1 \pm 1.2$ & $24 \pm 2$ & n.d. & $61 \pm 2$ & n.d. \\
\hline $\operatorname{HxCDD}(7)^{\mathrm{a}}$ & n.d. & n.d. & $32 \pm 2$ & n.d. & $108 \pm 2$ & n.d. \\
\hline$\Sigma \mathrm{HxCDD}$ & $11 \pm 0.6$ & $30 \pm 0.6$ & $220 \pm 2$ & n.d. & $728 \pm 3$ & $2.3 \pm 1$ \\
\hline $\operatorname{HxCDF}(1)^{\mathrm{a}}$ & n.d. & $1.1 \pm 0.4$ & $21 \pm 2$ & n.d. & n.d. & n.d. \\
\hline $\operatorname{HxCDF}(2)^{\mathrm{a}}$ & n.d. & $1.0 \pm 0.3$ & n.d. & n.d. & n.d. & n.d. \\
\hline $1,2,3,4,7,8-\mathrm{HxCDF}$ & n.d. & $1.1 \pm 0.3$ & n.d. & n.d. & n.d. & n.d. \\
\hline $2,3,4,6,7,8-\mathrm{HxCDF}$ & $64 \pm 3$ & $11 \pm 2$ & $63 \pm 2$ & $1.5 \pm 1$ & n.d. & $18 \pm 2$ \\
\hline $1,2,3,7,8,9-\mathrm{HxCDF}$ & n.d. & $1.0 \pm 0.3$ & n.d. & n.d. & n.d. & n.d. \\
\hline$\Sigma \mathrm{HxCDF}$ & $64 \pm 3$ & $15 \pm 2$ & $84 \pm 2$ & $1.5 \pm 1$ & n.d. & $18 \pm 2$ \\
\hline $\operatorname{PeCDD}(1)^{\mathrm{a}}$ & n.d. & n.d. & $6.2 \pm 1$ & n.d. & $8.5 \pm 2$ & n.d. \\
\hline $\operatorname{PeCDD}(2)^{\mathrm{a}}$ & n.d. & n.d. & n.d. & n.d. & $6.7 \pm 1$ & n.d. \\
\hline $\operatorname{PeCDD}(3)^{\mathrm{a}}$ & n.d. & n.d. & n.d. & n.d. & $4.8 \pm 1$ & n.d. \\
\hline $\operatorname{PeCDD}(4)^{\mathrm{a}}$ & n.d. & n.d. & n.d. & n.d. & $8.5 \pm 2$ & n.d. \\
\hline $\operatorname{PeCDD}(5)^{\mathrm{a}}$ & n.d. & n.d. & n.d. & n.d. & $3.7 \pm 1$ & n.d. \\
\hline$\Sigma \mathrm{PeCDD}$ & n.d. & n.d. & $6.2 \pm 2$ & n.d. & $32 \pm 2$ & n.d. \\
\hline PeCDF & n.d. & n.d. & $8.0 \pm 2$ & n.d. & n.d. & n.d. \\
\hline$\Sigma \mathrm{PCDD} / \mathrm{Fs}$ & $3,673 \pm 8$ & $2,781 \pm 5$ & $5,639 \pm 6$ & $14 \pm 2$ & $3,591 \pm 6$ & $3,911 \pm 4$ \\
\hline
\end{tabular}

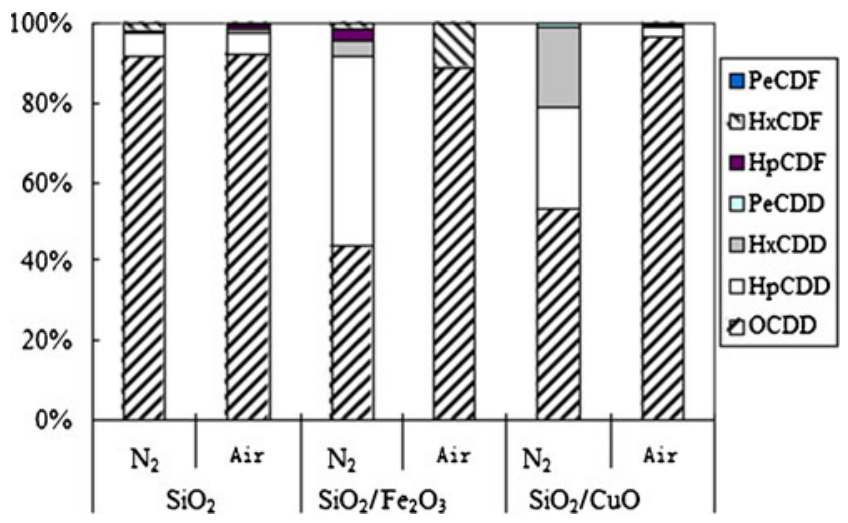

Fig. $3 \mathrm{PCDD} /$ Fs homologue patterns under nitrogen and air system may have promoted the reaction toward the direct oxidative ring-cracking decomposition of PCP and 1,2,4,5$\mathrm{Cl}_{4} \mathrm{Bz}$, and thus reduced the formation of PCDEs and PCDD/Fs on the $\mathrm{SiO}_{2} / \mathrm{Fe}_{2} \mathrm{O}_{3}$ surface.

It can be also seen that PCDDs are generally more common than PCDFs for all the reaction systems. The formation of PCDDs requires that a chlorine is available in the ortho position (Tuppurainen et al. 2003; Louw and Ahonkhai 2002). Because all the ortho positions on PCP are chlorinated, PCDDs become the major product over PCDFs. This is supported by the finding that the predominant PCDDs are formed from 2,4,6-trichlorophenol in heterogeneous reactions (Hell et al. 2000, 2001). The condensation between PCP and $1,2,4,5-\mathrm{Cl}_{4} \mathrm{Bz}$ could also lead to the formation of 
PCDEs, which are known to form PCDFs (and to a lesser degree PCDDs) upon pyrolysis (Liu et al. 2008). Therefore, PCDFs are harder to form from $\mathrm{PCP}$ and $1,2,4,5-\mathrm{Cl}_{4} \mathrm{Bz}$ in the heterogeneous reactions. However, it is worth mentioning that the yields of PCDEs are significantly lower than those of PCDD/Fs from the condensation of PCP and $1,2,4,5-\mathrm{Cl}_{4} \mathrm{Bz}$ on the $\mathrm{SiO}_{2} / \mathrm{CuO}$ and $\mathrm{SiO}_{2} / \mathrm{Fe}_{2} \mathrm{O}_{3}$ simulated fly ash surfaces in the flow reactor system under nitrogen.

The formation of PCDEs is significantly different from PCDD/Fs formation on $\mathrm{SiO}_{2} / \mathrm{Fe}_{2} \mathrm{O}_{3}$ and on $\mathrm{SiO}_{2} / \mathrm{CuO}$. This could be induced by a competitive reaction between the absorbed species and a gas-phase molecule (Farquar et al. 2003; Lomnicki and Dellinger 2003a). The surfaceassociated chlorophenoxyl can react with gas-phase chlorobenzenes to form PCDEs, with another vicinal chlorophenoxyl via a Langmuir-Hinshelwood pathway to form PCDF, and with gas-phase polychlorophenol via an EleyRideal pathway to form PCDD. The differences between Langmuir-Hinshelwood and Eley-Rideal mechanisms could result in significant differences in the reaction rates. The differences of the mechanisms can explain the observed differences between the formation of PCDEs and PCDD/Fs.

\section{Conclusions}

The present study clearly demonstrated that $\mathrm{Fe}_{2} \mathrm{O}_{3}$ and $\mathrm{CuO}$ affect the formation of PCDEs from the heterogeneous reactions of precursors. The 2,2',3,4,4',5,5',6-OCDE formed from the condensation of $\mathrm{PCP}$ and $1,2,4,5-\mathrm{Cl}_{4} \mathrm{Bz}$ is the predominant congener formed on the surface of the $\mathrm{SiO}_{2} / \mathrm{Fe}_{2} \mathrm{O}_{3}$ with and without oxygen. However, DecaCDE, NonaCDE, and OCDE were the dominant products on the $\mathrm{SiO}_{2} / \mathrm{CuO}$ surface without oxygen, although the $2,2^{\prime}, 3,4,4^{\prime}, 5,5^{\prime}, 6-\mathrm{OCDE}$ was the dominant product on the $\mathrm{SiO}_{2} / \mathrm{CuO}$ surface with oxygen. The presence of $\mathrm{Fe}_{2} \mathrm{O}_{3}$ and $\mathrm{CuO}$ influences the formation and homologue distribution of PCDEs, and results in an increase in the lower chlorinated PCDEs contribution from heterogeneous reactions. The amount of total PCDEs formed was higher, and the PCDE congener species were more complicated on the surface of $\mathrm{SiO}_{2} / \mathrm{Fe}_{2} \mathrm{O}_{3}$ without oxygen than on that with oxygen. In contrast, although the PCDEs formed were more complex, the amount of total PCDEs formed was lower on the surface of $\mathrm{SiO}_{2} / \mathrm{CuO}$ under nitrogen than on that in air. $\mathrm{Fe}_{2} \mathrm{O}_{3}$ can catalyze both the condensation and dechlorination reaction without oxygen. On the contrary, with oxygen, $\mathrm{Fe}_{2} \mathrm{O}_{3}$ suppress the condensation of chlorobenzene and chlorophenol to form PCDEs and PCDD/Fs. $\mathrm{CuO}$ can increase the formation of lower chlorinated PCDEs and PCDDs without oxygen. Moreover, abundant $\mathrm{PCDD} / \mathrm{F}$ was produced from the reactions of $\mathrm{PCP}$ and $1,2,4,5-\mathrm{Cl}_{4} \mathrm{Bz}$ during the process of PCDE formation.
Acknowledgments This study was supported by the National Natural Science Foundation of China (21037003), the National 973 program (2009CB421606), and open fund of State Key Laboratory of Environmental Chemistry and Ecotoxicology, Research Center for Eco-Environmental Sciences, Chinese Academy of Sciences (KF2012-10).

\section{References}

Addink R, Olie K (1995) Mechanisms of formation and destruction of polychlorinated dibenzo-p-dioxins and dibenzofurans in heterogeneous systems. Environ Sci Technol 29:1425-1435

Altarawneh M, Dlugogorski BZ, Kennedy EM, Mackie JC (2009) Mechanisms for formation, chlorination, dechlorination and destruction of polychlorinated dibenzo- $p$-dioxins and dibenzofurans (PCDD/Fs). Prog Energy Combust Sci 35:245-274

Ballschmiter K, Braunmiller I, Niemczyk M, Swerev M (1988) Reaction pathway for the formation of polychloro-dibenzodioxins (PCDD) and -dibenzofurans (PCDF) in combustion processes: II. Chlorobenzenes and chlorophenols as precursors in the formation of polychloro-dibenzdioxins and -dibenzofurans in flame chemistry. Chemosphere 17:995-1005

Bozzelli JW, Wu YPG, Ritter ER (1991) Thermodynamic insights on pathways to formation of chlorinated dioxins and dibenzofurans. Chemosphere 23:1221-1232

Chin YT, Lin C, Chang-Chien GP, Wang YM (2012) PCDD/F formation catalyzed by the metal chlorides and chlorinated aromatic compounds in fly ash. Aerosol Air Qual Res 12:228-236

Domingo JL, Bocio A, Falcó G, Llobet JM (2006) Exposure to PBDEs and PCDEs associated with the consumption of edible marine species. Environ Sci Technol 40:4394-4399

Farquar GR, Alderman SL, Poliakoff ED, Dellinger B (2003) X-ray spectroscopic studies of the high temperature reduction of $\mathrm{Cu}(\mathrm{II}) \mathrm{O}$ by 2 -chlorophenol on a simulated fly ash surface. Environ Sci Technol 37:931-935

Fujimori T, Takaoka M, Takeda $\mathrm{N}$ (2009) Influence of $\mathrm{Cu}, \mathrm{Fe}, \mathrm{Pb}$, and $\mathrm{Zn}$ chlorides and oxides on formation of chlorinated aromatic compounds in MSWI fly ash. Environ Sci Technol 43:8053-8059

Hell K, Altwicker ER, Stieglitz L, Addink R (2000) Comparison of 2,4,6-trichlorophenol to PCDD/Fs on MSWI fly ash and a model fly ash. Chemosphere 40:995-1001

Hell K, Stieglitz L, Altwicker ER, Addink R, Will R (2001) Reaction 2,4,6-trichlorophenol on model fly ash: oxidation to $\mathrm{CO}$ and $\mathrm{CO}_{2}$. Condensation to $\mathrm{PCDD} / \mathrm{Fs}$ and conversion into related compounds. Chemosphere 42:697-702

Hetrick CE, Lichtenberger J, Amiridis MD (2008) Catalytic oxidation of chlorophenol over $\mathrm{V}_{2} \mathrm{O}_{5} / \mathrm{TiO}_{2}$ catalysts. Appl Catal B Environ $77: 255-263$

Koistinen J, Koivusaari J, Nuuja I, Paasivirta J (1995a) PCDEs, PCBs, PCDDs and PCDFs in black guillemots and white-tail sea eagles from the Baltic Sea. Chemosphere 30:1671-1684

Koistinen J, Passivirta J, Suonperä M (1995b) Contamination of Pike and sediment from the Kymijoki River by PCDEs, PCDDs, and PCDFs: contents and patterns compared to Pike and sediment from the Bothnian Bay and seals from Lake Saimaa. Environ Sci Technol 29:2541-2547

Koistinen J, Stenman O, Haahti H, Suonperä M, Paasivirta J (1997) Polychlorinated diphenyl ethers, dibenzo- $p$-dioxins, dibenzofurans and biphenyls in seals and sediment from the Gulf of Finland. Chemosphere 35:1249-1269

Krishnamoorthy S, Rivas JA, Amiridis MD (2000) Catalytic oxidation of 1,2-dichlorobenzene over supported transition metal oxides. J Catal 193:264-272 
Kurz J, Ballschmiter K (1995) Isomer-specific determination of 79 polychlorinated diphenyl ethers (PCDE) in cod liver oil, chlorophenols and in a fly ash. Fresenius J Anal Chem 351:98-109

Lomnicki S, Dellinger B (2003a) A detailed mechanism of the surfacemediated formation of $\mathrm{PCDD} / \mathrm{F}$ from the oxidation of 2-chlorophenol on a $\mathrm{CuO} /$ Silica surface. J Phys Chem A 107:4387-4395

Lomnicki S, Dellinger B (2003b) Development of supported iron oxide catalyst for destruction of PCDD/F. Environ Sci Technol 37:4254-4260

Lindahl R, Rappe C, Buser HR (1980) Formation of polychlorinated dibenzofurans (PCDFs) and polychlorinated dibenzo-p-dioxin (PCDDs) from the pyrolysis of polychlorinated diphenyl ethers. Chemosphere 9:351-361

Liu W, Zheng M, Liu W, Gao L, Su G, Zhang B (2011) Mechanism of polychlorinated diphenyl ether formation on a simulated fly ash surface. J Hazard Mater 186:814-819

Liu W, Zheng M, Liu W, Ma X, Qian Y, Zhang B (2008) Formation of polychlorinated diphenyl ethers from condensation of chlorophenols with chlorobenzenes. Environ Sci Pollut Res 15:84-88

Louw R, Ahonkhai S (2002) Radical/radical versus radical/molecule reactions in the formation of $\mathrm{PCDD} /$ Fs from (chloro)phenols in incinerators. Chemosphere 46:1273-1278

McKay G (2002) Dioxin characterisation, formation and minimisation during municipal solid waste (MSW) incineration: review. Chem Eng J 86:343-368

Milligan MS, Altwicker ER (1996) Chlorophenol reaction on fly ash. 1. Adsorption/desorption equilibria and conversion to polychlorinated dibenzo-p-dioxins. Environ Sci Technol 30:225-229

Nevalainen T, Koistinen J (1994) Synthesis, structure, verification, and chematographic relative retention times for polychlorinated diphenyl ethers. Environ Sci Technol 28:1341-1347

Niimi AJ, Metcalfe CD, Huestis SY (1994) Chlorinated diphenyl ethers in Great Lakes fish and their environmental implication. Environ Toxicol Chem 13:1133-1138

Nito S, Akimoto Y, Imagawa T, Inouye Y (1997) Comparative study on formation of polychlorinated dibenzo- $p$-dioxin, polychlorinated dibenzofuran and related compounds by pyrolysis of some precursors on unused sand for fluidized bed incinerator and long term used sand. Chemosphere 35:1717-1727

Norström A, Andersson K, Rappe C (1977) Studies of the formation of chlorodibenzofurans by irradiation or pyrolysis of chlorinated diphenyl ether. Chemosphere 5:241-248

Öberg T, Bergbäck B, Filipsson M (2008) Catalytic effects by metal oxides on the formation and degradation of chlorinated aromatic compounds in fly ash. Chemosphere 71:1135-1143
Olie K, Vermeulen PL, Hutzinger O (1977) Chlorodibenzo-p-dioxins and chlorodibenzofurans are trace components of fly ash and flue gas of some municipal incinerators in the Netherlands. Chemosphere 6:455-459

Passivirta J, Tarhanen J, Soikkeli J (1986) Occurrence and fate of polychlorinated aromatic ethers (PCDE, PCA, PCV, PCPA and PCBA) in environment. Chemosphere 15:1429-1433

Qian Y, Zheng M, Liu W, Ma X, Zhang B (2005) Influence of metal oxides on PCDD/Fs formation from pentachlorophenol. Chemosphere 60:951-958

Sinkkonen S, Paasivirta J (2000) Polychlorinated organic compounds in the Arctic cod liver: trend and profiles. Chemosphere 40:619626

Stanley JS, Cramer PH, Ayling RE, Thornburg KR, Remmers JC, Breen JJ, Schwemberger J (1990) Determination of the prevalence of polychlorinated diphenyl ethers (PCDPES) in human adipose tissue samples. Chemosphere 20:981-985

Shi LS, Yuan LB (1996) Mechanism research of copper(II)-catalyzed polymerization of 2,4,6-trichlorophenols. J Appl Polym Sci 61:1279-1285

Tuppurainen K, Asikainen A, Ruokojägvi P, Ruuskanen J (2003) Perspectives on the formation of polychlorinated dibenzo-pdioxins and dibenzofurans during municipal solid waste (MSW) incineration and other combustion processes. Acc Chem Res $36: 652-658$

Tuppurainen K, Halonen I, Ruokojärvi P, Tarhanen J, Ruuskanen J (1998) Formation of PCDDs and PCDFs in municipal waste incineration and its inhibition mechanisms: a review. Chemosphere 36:14931511

Weber R, Takasuga T, Nagai K, Shiraishi H, Sakurai T, Matuda T, Hiraoka M (2002a) Dechlorination and destruction of PCDD, PCDF and PCB on selected fly ash from municipal waste incineration. Chemosphere 46:1255-1262

Weber R, Nagai K, Nishino J, Shiraishi H, Ishida M, Takasuga T, Konndo K, Hiraoka M (2002b) Effects of selected metal oxides on the dechlorination and destruction of PCDD and PCDF. Chemosphere 46:1247-1253

Xu HY, Zou JW, Hu GX, Wang W (2010) QSPR/QSAR models for prediction of the physico-chemical properties and biological activity of polychlorinated diphenyl ethers (PCDEs). Chemosphere 80:665-670

Zhang L, Zheng M, Liu W, Zhang B, Su G (2008) A method for decomposition of hexachlorobenzene by $\gamma$-alumina. J Hazard Mater 150:831-834 